\title{
PENGARUH DOSIS ROOTONE-F DAN PANJANG STEK TERHADAP PERTUMBUHAN STEK BUAH NAGA (Hylocereus polyrhizu)
}

\author{
I Putu Parmila1, Made Suarsana ${ }^{1}$, dan Wayan Poni Rahayu² \\ email: putu.parmila@unipas.ac.id \\ ${ }^{1}$ Staf edukatif Fakultas Pertanian Universitas Panji Sakti Singaraja \\ ${ }^{2}$ Alumni Fakultas Pertanian Universitas Panji Sakti Singaraja
}

\begin{abstract}
The purpose of this study was to determine each effect of Rootone-F dose, length of cuttings and interaction of Rootone-F dose treatment, length of dragon fruit cuttings. This study was a factorial experiment using a randomized block design (RBD) consisting of two factors, namely the first factor in administering Rootone-F $(R)$. with 4 levels of dosage treatment, namely: $0 \mathrm{mg}$. (RO), $20 \mathrm{mg}$. (R1), $40(R 2)$ and $60 \mathrm{mg}$. (R3). The second factor is the treatment of long dragon fruit cuttings, namely: $15 \mathrm{~cm}$. (P1) and $30 \mathrm{~cm} \mathrm{P2).} \mathrm{And} 45 \mathrm{~cm}$ (P3). The administration of Rootone-F significantly affected the total oven dry weight per plant, the total dry weight of the oven was obtained at the highest dose of $20 \mathrm{mg}$. (Rl) which is $19.69 \mathrm{~g}$. and it was not significantly different from giving a dose of rootone-F $0 \mathrm{mg}$. (RO) which is $11.63 \mathrm{~g} .(\mathrm{Rl}), 40$ which is $11.89 \mathrm{~g}$. (R2) and $60 \mathrm{mg}$ $(R 3)$ which is 11.23. Or with a ratio of Rootone-F $0 \mathrm{mg}$. (RO) which is $34.9 \%$, (R1) $2.23 \%$, (R2) the influence of Rootone-F on control and $0 \mathrm{mg}$. (RO) and $60 \mathrm{mg}$. (R3) gives negative results for $0 \mathrm{mg}$ control. (RO). The length of cuttings has a very significant effect on the total oven dry weight with a length of $45 \mathrm{~cm}(P 3)$ which is $18.13 \mathrm{~g}$, and is significantly different from the length of cuttings $30 \mathrm{~cm}(P 1)$ which is $16.07 \mathrm{~g}$ and the length of cuttings is $15 \mathrm{~cm}$. (P1) which is $3.63 \mathrm{~g}$.

Keywords: rootone-F, cuttings, dragon fruit
\end{abstract}

Abstrak: Tujuan penelitian ini adalah untuk mengetahui masing-masing pengaruh dosis Rootone-F, panjang stek dan interaksi perlakuan dosis Rootone-F, panjang stek buah naga. Penelitian ini merupakan percobaan faktorial dengan memakai rancangan acak kelompok (RAK) yang terdiri dua faktor, yaitu faktor pertama pemberian dosis Rootone-F (R). dengan 4 tingkat perlakuan dosis yaitu: $0 \mathrm{mg}$. $\left(\mathrm{R}_{0}\right), 20 \mathrm{mg}$. $\left(\mathrm{R}_{1}\right), 40\left(\mathrm{R}_{2}\right)$ dan 60 mg. $\left(R_{3}\right)$. Faktor kedua adalah perlakuan panjang stek buah naga yaitu: $15 \mathrm{~cm}$. $\left(\mathrm{P}_{1}\right)$ dan $\left.30 \mathrm{~cm} \mathrm{P}_{2}\right)$. Dan $45 \mathrm{~cm}$ $\left(\mathrm{P}_{3}\right)$. Pemberian Rootone-F berpengaruh nyata terhadap berat kering oven total per tanaman, berat kering oven total pertanaman teringgi di peroleh pada pemberian dosis $20 \mathrm{mg}$. $\left(\mathrm{R}_{1}\right)$ yaitu $19,69 \mathrm{~g}$. dan berbeda tidak nyata terhadap pemberian dosis rootone-F $0 \mathrm{mg}$. $\left(\mathrm{R}_{0}\right)$ yaitu $11,63 \mathrm{~g}$. $\left(\mathrm{R}_{1}\right), 40$ yaitu 11,89 g., $\left(\mathrm{R}_{2}\right)$ dan $60 \mathrm{mg}\left(\mathrm{R}_{3}\right)$ yaitu 11,23. Atau dengan perbandingan Rootone-F $0 \mathrm{mg}$. $\left(\mathrm{R}_{0}\right)$ yaitu $34,9 \%,\left(\mathrm{R}_{1}\right) 2,23 \%$, $\left(\mathrm{R}_{2}\right)$ pengaruh Rootone-F terhdap kontrol dan $0 \mathrm{mg}$. $\left(\mathrm{R}_{0}\right)$ dan $60 \mathrm{mg}$. $\left(\mathrm{R}_{3}\right)$ memberikan hasil negative terhadap kontrol $0 \mathrm{mg}$. $\left(\mathrm{R}_{0}\right)$. Panjang stek berpengaruh sangat nyata terhadap berat kering oven total dengan panjang $45 \mathrm{~cm}\left(\mathrm{P}_{3}\right)$ yaitu 18,13 $\mathrm{g}$, dan berbeda nyata terhadap panjang stek $30 \mathrm{~cm}\left(\mathrm{P}_{1}\right)$ yaitu $16,07 \mathrm{~g}$ dan panjang stek $15 \mathrm{~cm}$. $\left(\mathrm{P}_{1}\right)$ yaitu 3,63 g. Kata kunci: rootone-F, stek, buah naga

\section{PENDAHULUAN}

Kabupaten Buleleng memiliki luas wilayah $136.588 \mathrm{Ha}$, dengan luas lahan kering seluas 82.274,85 Ha. Luas lahan kering di Buleleng yang belum maksimal pemanfaatannya menjadikan satu potensi untuk pengembangan tanaman buah naga (BPS Buleleng, 2016). Buah naga (Hylocereus polyrhizus) atau Dragon Fruits merupakan salah satu komoditas yang cukup diminati di Indonesia karena bentuknya unik dan menarik serta rasanya yang enak. Buah naga juga berkhasiat untuk berbagai penyakit dan bermanfaat sebagai bahan baku di bidang industri pengolahan makanan, minuman, kosmetik serta produk kesehatan (Anonim, 2008).
Tanaman buah naga dapat diperbanyak dengan menggunakan biji maupun stek. Petani umumnya lebih memilih memperbanyak dengan stek karena menghasilkan bibit dalam waktu yang lebih singkat dibandingkan dengan biji. Penyetekan merupakan cara pembiakan tanaman dengan menggunakan bagian-bagian vegetatif yang dipisahkan dari induknya, apabila ditanam pada kondisi menguntungkan akan berkembang menjadi tanaman sempurna dengan sifat yang sama dengan pohon induk (Febriana, 2009).

Rootone-F merupakan salah satu hormon yang komersial. Bahan aktif mengandung auksin, yaitu hormon 
tanaman seperti indolasetat yang berfungsi untuk merangsang pembesaran sel gunanya untuk merangsang pertumbuhan akar pada stekan atau cangkokan (Anonim, 2010).

Kriteria bibit yang baik adalah batang berwarna hijau kebiruan atau hijau gelap, penampilan fisik kekar dan keras serta tampak tua. Ukuran stek yang ideal untuk bibit stek batang adalah dengan panjang antara $20-30 \mathrm{~cm}$.

Keberhasilan stek dicirikan oleh didapatnya bibit yang memiliki perakaran dan pertumbuhan yang baik dalam jumlah yang banyak pada satuan waktu tertentu (Pranoto, 1986). Fungsi dari akar yaitu menyerap air dan mineral terlarut, transportasi unsur hara, pengokoh batang dan penyimpan cadangan makanan. Semakin panjang akar yang terbentuk semakin memudahkan tanaman dalam menjalankan fungsinya, salah satunya dalam penyerapan unsur hara.

Untuk mendapatkan bibit buah naga yang baik dan berkualitas maka, dilakukan penelitian pengaruh dosis Rootone-F dan panjang stek terhadap pertumbuhan tunas buah naga dan interaksi dari kedua perlakuan.

Tujuan Penelitian ini bertujuan untuk mengetahui masing-masing pengaruh dosis rootone- $F$ dan panjang stek, dan untuk mengetahui interaksi perlakuan dosis rootone-F dengan panjang stek buah naga.

\section{BAHAN DAN METODE}

Tempat dan Waktu Penelitian

Penelitian ini dilaksanakan di Lahan Pembibitan Kelompok Tani Ternak Kerti Winangun. Desa Bukti, Kecamatan Kubutambahan, Kabupaten Buleleng. Kelompok Tani Ternak Kerti Winangun terletak dilereng perbukitan yang memiliki ketinggian \pm 50 meter dari atas permukaan laut. Penelitian ini dilaksanakan pada bulan Maret - Juni 2016.

Bahan yang digunakan pada percobaan ini adalah: Bibit buah naga (Hylocereus polyrhizus) merah keunguan,
Rotoone-F, Tanah, Pupuk kandang, Pasir, Polybag dengan ukuran tinggi $35 \mathrm{~cm}$ dan panjang alas $17,5 \mathrm{~cm}$.

Alat yang digunakan yaitu :Gunting pangkas, Label nama untuk tempat menulis perlakuan, Ember untuk mengukur volume media, Penggaris, untuk mengukur panjang tunas dan panjang akar, Timbangan, untuk menimang bahan maupun hasil pengamatan, Ajir untuk menopang bibit buah naga, Oven, sebagai alat untuk mengeringkan, dan Alat tulis menulis

Metode yang digunakan dalam percobaan ini adalah metode eksperimen, dengan menggunakan RAK (Rancangan Acak Kelompok). Perlakuan disusun secara faktorial dengan dua faktor, yaitu faktor Rootone-F (R) dan panjang stek (P) buah naga.

Perlakuan dosis Rootone-F (R) terdiri atas empat aras, yaitu : $\mathrm{R}_{0}: 0$ $\mathrm{mg}$ rootone-F/stek, $\mathrm{R}_{1}$ : $20 \mathrm{mg}$ rootone$\mathrm{F} / \mathrm{stek}, \mathrm{R}_{2} \quad: 40 \mathrm{mg}$ rootone-F/stek, $\mathrm{R}_{3}$ : $60 \mathrm{mg}$ rootone-F/stek. Perlakuan pengaruh panjang stek terdiri atas tiga aras, yaitu : $\mathrm{P}_{1}$ : Panjang stek $15 \mathrm{~cm}, \mathrm{P}_{2}$ : Panjang stek $30 \mathrm{~cm}, \mathrm{P}_{3}$ : Panjang stek $45 \mathrm{~cm}$ Kedua faktor perlakuan dikombinasikan yaitu 4 perlakuan dosis rootone-F dikali 3 perlakuan panjang stek menghasilkan 12 $(4 \times 3)=12$ perlakuan kombinasi.

Seluruh kombinasi perlakuan diulang sebanyak tiga kali, yaitu 12 perlakuan di kali 3 ulangan sehingga terdapat $36(12 \times 3)=36$ unit percobaan. Masing-masing unit percobaan terdiri dari 10 pot dan tanaman sehingga terdapat 360 pot dan tanaman. Seluruh perlakuan diacak pada setiap ulangan.

Pengamatan dilakukan satu minggu sekali sampai stek berumur 83 hari setelah tanam. Pengamatan pertama dilakukan mulai pada umur 28 hari setelah tanam. Variabel yang diamati dalam penelitian ini sebagai berikut : 1) Jumlah tunas (batang), 2) Panjang tunas (cm), 3) Lingkar batang semu (cm), 4) Jumlah akar lateral (helai), 5) Panjang akar per stek (cm ), 6) Volume akar (mm), 7) Berat basah tunas (g), 8) 
Berat basah akar $(\mathrm{g}), 9)$ Berat basah total $(\mathrm{g}), 10)$ Berat kering oven tunas $(\mathrm{g}), 11)$ Berat kering oven akar (g), 12) Berat kering oven total (g) 13) Hasil penelitian ini dianalisis secara statistika sesuai dengan rancangan yang digunakan, yaitu Rancangan Acak Kelompok (RAK). Apabila antara perlakuan menunjukkan perbedaan yang nyata, dilanjutkan dengan uji BNT pada taraf 5\%. Apabila pengaruh interaksi berbeda nyata atau sangat nyata, dilanjutkan dengan uji Duncan taraf 5\% (Hanafiah, 2001).

\section{HASIL DAN PEMBAHASAN}

Data hasil pengamatan dari analisis ragam pengaruh perlakuan terhadap variabel yang di amati menunjukkan pemberian Rootone- $F$ berpengaruh nyata $(p<0,05)$ terhadap berat kering oven total dan berpengaruh sangat nyata $(\mathrm{p}<0,01)$ terhadap jumlah akar lateral, tetapi berpengaruh tidak nyata $(\mathrm{p} \searrow 0,05)$ terhadap jumlah tunas pada umur 63 hst sampai dengan 83 hst, panjang tunas pada umur 63 hst sampai 83 hst, lingkar batang semu pada umur 63hst sampai dengan 83 hst, panjang akar, volume akar, berat basah tunas, berat basah akar, berat basah total, berat kering oven tunas, berat kering oven akar.

Panjang stek berpengaruh sangat nyata $(\mathrm{p}<0,01)$ terhadap jumlah tunas pada umur 63 sampai dengan $83 \mathrm{hst}$, panjang tunas pada umur 63 hst sampai dengan 83 hst, lingkar batang semu pada umur $63 \mathrm{hst}$ sampai dengan 83 hst, jumlah akar lateral, volume akar, berat basah tunas, berat basah akar, berat basah toatal, berat kering oven tunas, berat kering oven akar, berat kering oven total. Data secara lengkap disajikan pada Tabel 1.

Interaksi antar pengaruh dosis Rootone-F dan Panjang stek berpengaruh nyata $(p<0,05)$ terhadap volume akar, berat basah akar, berat kering oven total dan berpengaruh sangat nyata $(\mathrm{p}<0,01)$ terhadap jumlah akar lateral, tetapi berpengaruh tidak nyata terhadap jumlah tunas pada umur 63 hst, sampai umur 83 hst, panjang tunas pada umur 63 hst sampai 83 hst, lingkar batang semu pada umur 63 sampai 83 hst, panjang akar, berat basah tunas, berat basah total, berat kering oven tunas dan berat kering oven akar.

Pemberian Rootone-F berpengaruh sangat nyata terhadap jumlah akar lateral (Tabel 1). Jumlah akar lateral per stek yang terbaik diberikan pada pemberian Rootone-F dosis $20 \mathrm{mg}\left(\mathrm{R}_{1}\right)$ yaitu 7,67 helai, dan berpengaruh sangat nyata terhadap penggunaan Rootone-F $0 \mathrm{mg}$ $\left(\mathrm{R}_{0}\right), 40 \mathrm{mg}\left(\mathrm{R}_{2}\right)$ dan $60 \mathrm{mg}\left(\mathrm{R}_{3}\right)$ yaitu 6,11 helai, 7,33 helai, 7,30 helai

Panjang stek berpengaruh sangat nyata terhadap jumlah akar lateral (Tabel 1). Jumlah akar lateral yang terbaik terdapat pada panjang stek $45 \mathrm{~cm}\left(\mathrm{P}_{3}\right)$ yaitu 7,86 helai, Panjang stek berpengaruh sangat nyata terhadap panjang akar (Tabel 2). Panjang akar yang terbaik terdapat pada panjang stek $45 \mathrm{~cm}\left(\mathrm{P}_{3}\right)$ yaitu 36,80 $\mathrm{cm}$, Panjang stek berpengaruh sangat nyata terhadap volume akar volume akar yang terbaik terdapat pada panjang stek $45 \mathrm{~cm}$ $\left(\mathrm{P}_{3}\right)$ yaitu $21,00 \mathrm{~mm}$, panjang stek berpengaruh sangat nyata terhadap berat basah tunas (Tabel 2). Berat basah tunas yang terbaik terdapat pada panjang stek 45 cm $\left(\mathrm{P}_{3}\right)$ yaitu 137,42 g, Panjang stek berpengaruh sangat nyata terhadap berat basah akar (Tabel 1). Berat basah akar yang terbaik terdapat pada panjang stek 45 $\mathrm{cm}\left(\mathrm{P}_{3}\right)$ yaitu $32,94 \mathrm{~g}$.

Panjang stek berpengaruh sangat nyata terhadap berat kering oven akar (Tabel 2). Berat kering oven akar yang terbaik terdapat pada panjang stek $45 \mathrm{~cm}$ $\left(\mathrm{P}_{3}\right)$ yaitu 9,91 g. Pemberian Rootone-F berpengaruh nyata terhadap berat kering oven total per tanaman (Tabel 2). Berat kering oven total per tanaman terbaik diperoleh pada penggunaan Rootone-F dosis $20 \mathrm{mg}\left(\mathrm{R}_{1}\right)$ yaitu 15,69 $\mathrm{g}$, dibandingkan dengan berat kering oven total per stek pada tanpa penggunaan Rootone-F $\left(\mathrm{R}_{0}\right)$ Hasil analisis regresi hubungan antara dosis Rootone-F (x) dan berat kering oven total per tanaman $(\hat{\mathrm{Y}})$ menunjukkan hubungan kuadratik dengan 
persamaan, yaitu $\hat{\mathrm{Y}}=-0,002 \mathrm{x}^{2}+0,151 \mathrm{x}+$ 12,18 dengan koefisien determinasi $\left(\mathrm{R}^{2}\right)=$
$0,529 \%$ sehingga diperoleh $\mathrm{X}_{\mathrm{opt}}=37,75$ $\mathrm{mg}$, dan $\hat{\mathrm{Y}}_{\max }=15,03 \mathrm{~g}$.

Tabel 1. Pengaruh dosis Rootone- F dan panjang stek terhadap berat basah tunas, berat basah akar, dan berat basah total

\begin{tabular}{|c|c|c|c|c|c|c|}
\hline \multirow[b]{2}{*}{ Perlakuan } & \multicolumn{6}{|c|}{ Berat Basah Tanaman } \\
\hline & $\begin{array}{c}\text { Berat Basah } \\
\text { Tunas }(\mathrm{g})\end{array}$ & & $\begin{array}{c}\text { Berat Basah } \\
\text { akar }(\mathrm{g})\end{array}$ & & $\begin{array}{c}\text { Berat Basah } \\
\text { Total }(\mathrm{g})\end{array}$ & \\
\hline Rootone-F (R) & & & & & & \\
\hline $0 \mathrm{mg}\left(\mathrm{R}_{0}\right)$ & 87,00 & $\mathrm{a}$ & 19,37 & $\mathrm{a}$ & 106,37 & $\mathrm{a}$ \\
\hline $20 \mathrm{mg}\left(\mathrm{R}_{1}\right)$ & 129,78 & $\mathrm{a}$ & 23,56 & $\mathrm{a}$ & 153,33 & $\mathrm{a}$ \\
\hline $40 \mathrm{mg}\left(\mathrm{R}_{2}\right)$ & 105,63 & $\mathrm{a}$ & 20,07 & $\mathrm{a}$ & 128,70 & $\mathrm{a}$ \\
\hline $60 \mathrm{mg}\left(\mathrm{R}_{3}\right)$ & 90,44 & $\mathrm{a}$ & 18,95 & $\mathrm{a}$ & 109,40 & $\mathrm{a}$ \\
\hline Panjang Stek (F & & & & & & \\
\hline $15 \mathrm{~cm}\left(\mathrm{P}_{1}\right)$ & 42,44 & $\mathrm{~b}$ & 6,72 & $c$ & 49,17 & b \\
\hline $30 \mathrm{~cm}\left(\mathrm{P}_{2}\right)$ & 132,03 & $\mathrm{a}$ & 21,81 & $\mathrm{~b}$ & 153,83 & $\mathrm{a}$ \\
\hline $45 \mathrm{~cm}\left(\mathrm{P}_{3}\right)$ & 137,42 & $\mathrm{a}$ & 32,94 & $\mathrm{a}$ & 170,36 & $\mathrm{a}$ \\
\hline
\end{tabular}

Keterangan: Angka-angka yang diikuti oleh huruf yang sama pada perlakuan dan variabel yang sama menunjukkan perbedaan yang tidak nyata pada uji BNT 0,05

Panjang stek berpengaruh sangat nyata terhadap berat kering oven total (Tabel 2). Berat kering oven total yang terbaik terdapat pada panjang stek $45 \mathrm{~cm}$ $\left(\mathrm{P}_{3}\right)$ yaitu $18,13 \mathrm{~g}$, Hasil analisis regresi hubungan antara panjang stek dan berat kering oven total per stek $\hat{Y}$ menunjukkan hubungan kuadratik dengan persamaan, yaitu $\hat{Y}=-0,023 x^{2}+1,865 x-19,16$ dengan koefisien determinasi $\left(\mathrm{R}^{2}\right) \quad 0,970 \%$ sehingga diperoleh $\hat{\mathrm{Y}}_{\max }=18,65 \mathrm{~g}$ dengan panjang stek $X_{\mathrm{opt}}=40,54 \mathrm{~cm}$

Tabel 2. Pengaruh dosis Rootone-F dan panjang stek terhadap berat kering oven tunas, berat kering oven akar, berat kering oven total

\begin{tabular}{|c|c|c|c|c|c|c|}
\hline \multirow[b]{2}{*}{ Perlakuan } & \multicolumn{6}{|c|}{ Berat Kering Oven Tunas } \\
\hline & $\begin{array}{c}\text { Berat Kering } \\
\text { Oven Tunas } \\
\quad(\mathrm{g})\end{array}$ & & $\begin{array}{c}\text { Berat } \\
\text { Kering } \\
\text { Oven Akar } \\
\text { (g) }\end{array}$ & & $\begin{array}{c}\text { Berat } \\
\text { Kering } \\
\text { Oven Total } \\
(\mathrm{g})\end{array}$ & \\
\hline \multicolumn{7}{|l|}{ Rootone-F (R) } \\
\hline $0 \mathrm{mg}\left(\mathrm{R}_{0}\right)$ & 5,16 & $\mathrm{a}$ & 6,47 & $\mathrm{a}$ & 11,63 & $\mathrm{~b}$ \\
\hline $20 \mathrm{mg}\left(\mathrm{R}_{1}\right)$ & 8,59 & $\mathrm{a}$ & 7,10 & $\mathrm{a}$ & 15,69 & $\mathrm{a}$ \\
\hline $40 \mathrm{mg}\left(\mathrm{R}_{2}\right)$ & 6,80 & $\mathrm{a}$ & 6,20 & $\mathrm{a}$ & 11,89 & $\mathrm{~b}$ \\
\hline $60 \mathrm{mg}\left(\mathrm{R}_{3}\right)$ & 5,19 & $\mathrm{a}$ & 6,03 & $\mathrm{a}$ & 11,23 & $\mathrm{~b}$ \\
\hline \multicolumn{7}{|c|}{ Panjang Stek $(\mathrm{P})$} \\
\hline $15 \mathrm{~cm}\left(\mathrm{P}_{1}\right)$ & 1,35 & b & 2,28 & $\mathrm{c}$ & 3,63 & $\mathrm{~b}$ \\
\hline $30 \mathrm{~cm}\left(\mathrm{P}_{2}\right)$ & 8,90 & $\mathrm{a}$ & 7,17 & $\mathrm{~b}$ & 16,07 & $\mathrm{a}$ \\
\hline $45 \mathrm{~cm}\left(\mathrm{P}_{3}\right)$ & 9,06 & $\mathrm{a}$ & 9,91 & $\mathrm{a}$ & 18,13 & $\mathrm{a}$ \\
\hline
\end{tabular}

Keterangan : Angka-angka yang diikuti oleh huruf yang sama pada perlakuan dan variabel yang sama menunjukkan perbedaan yang tidak nyata pada uji BNT 0,05 


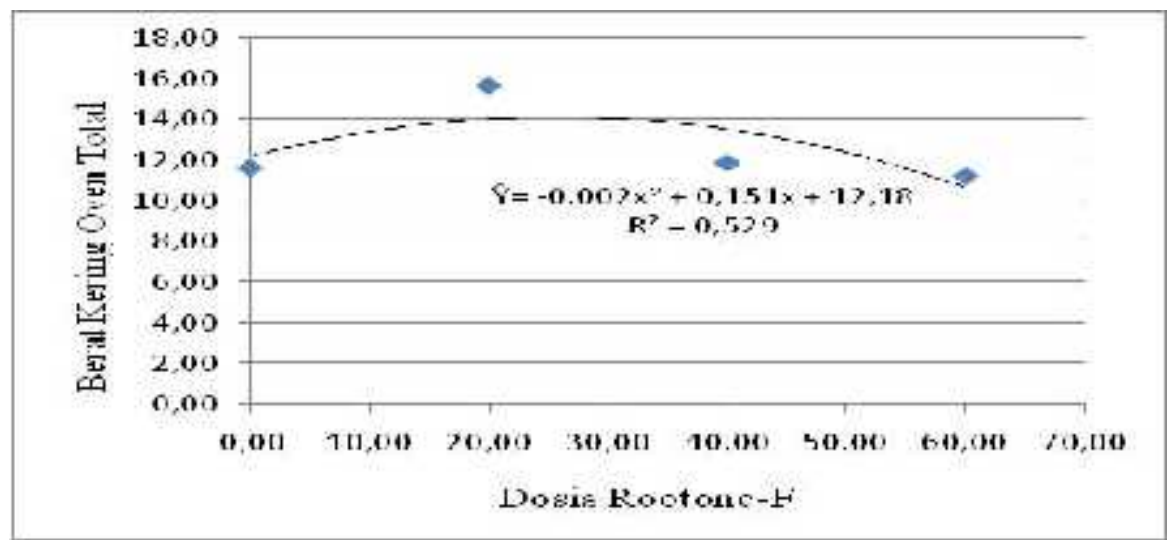

Gambar 1. Hubungan antara dosis Rootone-F dan berat kering oven total per tanaman

Berdasarkan hasil statistika menunjukkan bahwa pemberian dosis Rootone-F berpengaruh tidak nyata $(\mathrm{P} \searrow 0,05)$ terhadap sebagian besar variabel yang diamati, tetapi berpengaruh sangat nyata $(\mathrm{P}<0,01)$ terhadap berat kering oven total, dan interaksi pemberian Rootone-F dan Panjang stek hanya berpengaruh nyata terhadap berat kering oven total.

Perlakuan Zat Pengatur Tumbuh Rootone-F berpengaruh nyata $(\mathrm{p}<0,05)$ terhadap berat kering oven total dan berpengaruh sangat nyata $(\mathrm{p}<0,01)$ terhadap jumlah akar lateral, tetapi berpengaruh tidak nyata terhadap jumlah tunas pada umur 63 hst sampai dengan 83 hst, panjang tunas pada umur 63 hst sampai dengan 83 hst, lingkar batang semu pada umur 63 hst sampai dengan 83 hst, panjang akar, volume akar, berat basah tunas, berat basah akar, berat basah total, berat kering oven tunas, berat kering oven akar.

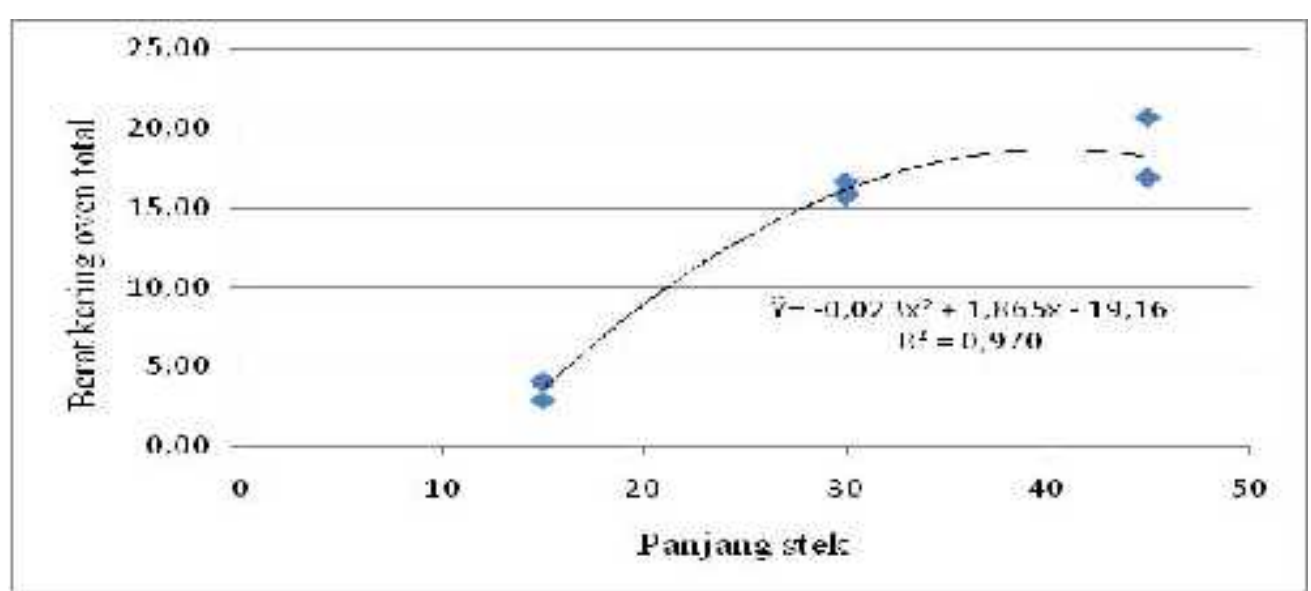

Gambar 2. Hubungan antara panjang stek dan berat kering oven total per tanaman.

Penggunan Rootone-F pada dosis $20 \mathrm{mg}$ memberikan pengaruh terhadap berat kering oven total terbaik dan dosis optimal dari pemberian Rootone-F berdasarkan model regresi $\hat{Y}=-0,002 x^{2}+$ $0,151 \mathrm{x}+12,18$ dengan koefisien determinasi $\left(\mathrm{R}^{2}\right)=0,529 \%$ didapatkan dosis optimal dari pemberian Rootone-F $\left(\mathrm{X}_{\mathrm{opt}}\right)$ adalah $37,75 \mathrm{mg}$, dangan berat kering oven optimal ( $\left.\hat{\mathrm{Y}}_{\max }\right)$ sebesar 15,03 g. Pemberian Rootone-F yang lebih tinggi dari dosis $37,75 \mathrm{mg}$ tentunya akan merugika tanaman, karena pertumbuhan tanaman/bibit akan menjadi tertekan. Hal ini dapat dijelaskan bahwa Rootone- $\mathrm{F}$ merupakan salah satu jenis zat pengatur tumbuh (ZPT) dapat efektif dalam memacu pertumbuhan tunas dan akar stek 
buah naga bila diberikan pada Kusumo (1984) bahwa zat pengantar tumbuh adalah senyawa organik bukan hara, yang dalam jumlah sedikit dapat merangsang, menghambat dan merubah proses fisiologi tumbuhan, sedangkan apabila diberikan dalam jumlah yang berlebihan dapat menggangu tanaman dan tanaman bisa mati.

Berpengaruhnya perlakuan dosis Rootone-F disebabkan oleh adanya kandungan empat jenis auksin sintetis yaitu 1-naftalenasetamida $0,067 \%$, 2metil-1-naftalenasetamida $0,13 \%$, 2-metil1-naftalena dan indol-3-butirat $0,057 \%$ Auksin sintetik seperti IAA (3-indoleacetic acid), NAA (1-naphtyl-acetic acid) memacu pertumbuhan stek melalui percepatan pembelahan sel kambium dan diferensiasi phloem dan xylem, merangsang inisiasi pembentukan akar dan diferensiasi jaringan akar (Watimena, 1998).

Dosis Rootone-F yang diberikan dapat memacu pertumbuhan akar dan tunas stek sehingga pertumbuhan stek menjadi lebih baik. Rootone-F mengandung NAA yang berfungsi sebagai stimulator pembelahan sel akar sehingga lebih memungkinkan terbentuknya sistem perakaran yang lebih baik, yang akhirnya dapat meningkatkan aktivitas fisiologis tanaman sehingga terjadi penyerapan air dan zat makanan oleh protoplast, selanjutnya akan diikuti proses pemanjangan sel akar. Hasil penelitian ini didukung oleh Kusumo (1984) menyatakan bahwa pemberian zat pengatur tumbuh dari luar akan dapat merangsang kegiatan auxin yang ada di dalam tanaman yang menyebabkan pengembangan dinding sel-sel akar sehingga sel akan membesar memanjang akibat dari aktivitas protoplast. Penggunaan RootoneF dosis $40 \mathrm{mg}$ sudah melebihi dosis optimum sehingga berefek negatif terhadap pertumbuhan jumlah akar per tanaman dan panjang akar. Seperti yang dinyatakan Hendaryono dan Wijayani (1994) yaitu zat pengatur tumbuh dengan dosis yang terlalu tinggi justru akan menghambat pertumbuhan kalus. Pada penelitian ini di atas dosis $37,75 \mathrm{~g}$ sudah menghambat pertumbuhan stek.

Semakin panjang akar terbentuk maka semakin besar kemampuan tanaman menyerap air, unsur hara dan mineralmineral lainnya yang penting dalam proses fisiologis dan pertumbuhan tanaman akan lebih terpenuhi. Semakin banyak unsur hara dan mineral-mineral penting yang terkandung dalam tanaman akan dapat meningkatkan pertumbuhan berat kering oven tunas per stek.

Pertumbuhan jumlah tunas terbaik diperoleh pada pemberian Rootone-F 40 mg yaitu 2,38 per batang stek. Perbedaan jumlah tunas untuk semua perlakuan dosis Rootone-F sesuai dengan pernyataan. (Wareing dan Philips, 1978 bahwa setiap jenis tanaman memerlukan konsentrasi yang tepat atau sesuai untuk pertumbuhannya. Pemberian dosis yang tidak sesuai tidak akan memacu pertumbuhan, justru dapat menghambat pertumbuhan.hal ini sesuai dengan fungsi dan kegunaannya, bahwa zat pengatur tumbuh Rootone-F merupakan senyawa atau zat kimia yang dalam konsentrasi rendah dapat merangsang, menghambat atau sebaliknya mengubah proses fisiologi dalam pertumbuhan dan perkembangan tanaman dimana hal ini tergantung dari tipe-tipe jenis tanaman atau sifat-sifat dari masing-masing jenis tersebut berasal.

Dengan berpengaruhnya pemberian Rootone-F terhadap perakaran, peningkatan berat kering tidak terlepas dari peranan tunas. Pada saat pertumbuhan tunas tidak semua mata tunas tumbuh serentak, bermula tumbuh satu tunas dan selanjutnya terjadi peningkatan jumlah tunas sesuai dengan umur tanaman sampai pada akhirnya tidak terdapat pertumbuhan tunas lagi hanya panjang tunas yang bertambah panjang.

Auksin berperan mengaktifasi pompa proton (ion $\mathrm{H}^{+}$) yang terletak pada membran plasma sehingga menyebabkan $\mathrm{pH}$ pada bagian dinding sel lebih rendah 
dari biasanya, yaitu mendekati $\mathrm{pH}$ pada membran plasma (sekitar $\mathrm{pH}$ 4,5 dari normal $\mathrm{pH}$ 7). Aktifnya pompa proton tersebut dapat memutuskan ikatan hidrogen diantara serat selulosa dinding sel. Putusnya ikatan hidrogen menyebabkan dinding mudah merenggang sehingga tekanan dinding sel akan menurun dan dengan demikian terjadilah pelenturan sel, sehingga pemanjangan dan pembesaran sel dapat dapat terjadi (Catala dkk, 2000).

Untuk meningkatkan laju pertumbuhan tanaman, pemberian ZPT perlu memperhatikan konsentrasi yang tepat. Hal ini sesuai dengan pendapat Abidin (1983) bahwa pemberian ZPT yang berlebihan pada tanaman akan menghambat pertumbuhan tanaman. Pendapat ini juga ditunjang oleh Wattimena (1987) bahwa respon tanaman atau bagian tanaman terhadap hormon yang diberikan akan berbeda-beda tergantung jenis tanaman, umur, keadaan lingkungan, tingkat perkembangan fisiologis terutama kandungan hormon endogen dan unsur hara.

Pengangkutan auksin hal yang mengherankan mengenai kemampuan IAA sebagai hormon ialah caranya diangkut dari satu organ atau jaringan ke organ atau jaringan lain. Berlainan dengan pergerakan gula, ion, dan linarut tertentu lainnya, IAA biasanyatidak dipindahkan melalui tabung tapis floem atau melalui xilem, tapi terutama melalui sel parenkima yang bersinggungan dengan berkas pembuluh IAA akan bergerak melalui tabung tapis jika diberikan dipermukaan daun yang cukup matang untuk mengangkut gula keluar, tapi biasanya pengangkutan pada batang dan tangkai daun berasal dari daun muda menuju arah bawah sepanjang berkas pembuluh. Bahkan auksin tiruan yang diberikan pada tumbuhan bergerak seperti IAA.

IAA terdapat di akar, pada konsentrasi yang hampir sama dengan di bagian tumbuhan yang lainnya. Seperti ketika pertama kali dikemukakan pada tahun 1930an, pemberian auksin memacu pemanjangan potongan akar atau bahkan akar utuh pada banyak spesis, tapi hanya pada konsentrasi yang sangat redah $\left(10^{-7}\right.$ sampai $10^{-3} \mathrm{M}$, bergantung pada spesies dan umur akar. Pada konsentrasi yang lebih tinggi (tapi masih cukup rendah, antara 1 sampai $10 \mu \mathrm{M}$ ), pemanjangan hampir selalu terhambat (Salisbury dan Ross, 1995).

Panjang stek berpengaruh sangat nyata $(p<0,01)$ terhadap semua variabel yang diamati hal ini disebabkan karena cadangan makanan pada stek tersebut telah mampu mendukung pertumbuhan bibit (Nuryana, 2012).

Penggunan Panjang stek berpengaruh sangat nyata terhadap berat kering oven total. Berat kering oven total yang terbaik terdapat pada panjang stek 45 cm $\left(\mathrm{P}_{3}\right)$ yaitu $18,13 \mathrm{~g}$, dan berbeda nyata dengan panjang stek $30 \mathrm{~cm}\left(\mathrm{P}_{2}\right)$ yaitu $16,07 \mathrm{~g}$, dan panjang stek $15 \mathrm{~cm}\left(\mathrm{P}_{1}\right)$ yaitu 3,63 g. Hasil analisis regresi hubungan antara panjang stek dan berat kering oven total per stek $\hat{Y}$ menunjukkan hubungan kuadratik dengan persamaan, yaitu $\hat{\mathrm{Y}}=$ $0,023 x^{2}+1,865 x-19,16$ dengan koefisien determinasi $\left(\mathrm{R}^{2}\right) \quad 0,970 \%$ sehingga diperoleh $\hat{\mathrm{Y}}_{\max }=18,65 \mathrm{~g}$ dengan panjang stek $\mathrm{X}_{\mathrm{opt}}=40$,

Panjang stek berpengaruh terhadap ukuran stek, semakin panjang ukuran bibit stek yang digunakan maka pertumbuhan panjang akar semakin baik karena lebih banyak cadangan makanan yang digunakan untuk mendukung pertumbuhan akarnya (Nuryani, 2012).

Umur bahan stek mempengaruhi terhadap kemampuannya membentuk akar. Stek yang berumur muda dan lunak proses transpirasinya akan berlagsung dengan cepat, sehingga stek menjadi lunak dan akhirnya mati. Stek dari tanaman yang berumur tua diperlukan waktu yang lama untuk keluarnya akar (Rochiman dan Harjadi, 2000).

Pertambahan panjang tunas bertambah seiring dengan lama waktu pengamatan. Hal ini disebabkan tanaman 
mulai merespon keberadaan zat pengatur tumbuh, sehingga perkembangan akar baik dan menyebabkan terjadinya peningkatan kapasitas penyerapan unsur-unsur hara dalam media oleh akar. Kondisi ini menyebabkan tanaman dapat melaksanakan proses fisiologisnya untuk pertumbuhan vegetatifnya (Hidayati dan Saefudin, 2002 dalam Sinambela, 2009).

Ukuran stek yang ideal antara (2030) $\mathrm{cm}$, dengan panjang stek tersebut maka tunas yang tumbuh akan mudah membesar dan sesuai untuk batang paling bawah bila ditanam untuk produksi. Selain itu stek dengan ukuran tersebut memiliki banyak mata tunas. Pengaruh banyak mata tunas ini tampak saat tunas baru yang baru tumbuh di pangkas maka akan muncul dua tunas baru yang terkadang hampir bersamaan.

Interaksi pemberian Rootone-F dan panjang stek berpengaruh nyata terhadap volume akar, berat basah akar dan berat kering oven total sampai berpengaruh sangat nyata terhadap jumlah akar lateral. Karena pengaruh pemberian Rootone-F dosis $20 \mathrm{mg}$ dan panjang stek $45 \mathrm{~cm}$ terjadi peningkatan volume akar yaitu $11,15 \%$ daripada $0 \mathrm{mg}$ dan panjang stek 15 $\mathrm{cm}\left(\mathrm{R}_{0} \mathrm{P}_{1}\right)$. Pemberian Rootone-F dosis 20 mg dengan panjang stek $45 \mathrm{~cm}\left(\mathrm{R}_{1} \mathrm{P}_{3}\right)$ dapat meningkatkan berat basah akar yaitu sebesar $9,71 \%$ daripada $0 \mathrm{mg}$ dan panjang stek $15 \mathrm{~cm}\left(\mathrm{R}_{0} \mathrm{P}_{1}\right)$. Pemberian Rootone-F dosis $20 \mathrm{mg}$ dan panjang stek $30 \mathrm{~cm}$ terjadi peningkatan berat kering oven total sebesar $10,92 \%$ daripada pemberian Rootone-F dosis $20 \mathrm{mg}$ dan panjang stek $15 \mathrm{~cm}$ dan pemberian Rootone-F dosis 20 mg dan panjang stek $45 \mathrm{~cm}$ terjadi peningkatan jumlah akar lateral sebesar $53,11 \%$ daripada $0 \mathrm{mg}$ dan panjang stek 15 $\mathrm{cm}$.

Panjang stek berpengaruh terhadap ukuran stek, semakin panjang ukuran bibit stek yang digunakan maka pertumbuhan panjang akar semakin baik karena lebih banyak cadangan makanan yang digunakan untuk mendukung pertumbuhan akarnya (Nuryani, 2012).
Ukuran stek yang ideal antara (2030) $\mathrm{cm}$, dengan panjang stek tersebut maka tunas yang tumbuh akan mudah membesar dan sesuai untuk batang paling bawah bila ditanam untuk produksi. Selain itu stek dengan ukuran tersebut memiliki banyak mata tunas. Pengaruh banyak mata tunas ini tampak saat tunas baru yang baru tumbuh di pangkas maka akan muncul dua tunas baru yang terkadang hampir bersamaan.

Dari hasil dan pembahasan diatas maka dapat di simpulkan sebagai berikut Semakin tinggi dosis Rootone-F maka berat kering oven total semakin tinggi, kemudian pertambahan berat kering oven total semakin berkurang. Dosis Rootone-F memberikan pengaruh terbaik terdapat pada dosis Rootone-F optimum yaitu $37,75 \mathrm{mg}$ yang menghasilkan berat kering oven yaitu 15,03 g., semakin panjang ukuran stek pertumbuhan tunas semakin tinggi, kemudian pada panjang stek tertentu pertumbuhan tunas berkurang. Panjang stek $45 \mathrm{~cm}$ memberikan pengaruh terbaik yaitu $18,13 \mathrm{~cm}$ dengan panjang stek optimum $40,54 \mathrm{~cm}$., pada berbagai variasi dosis Rootone-F memberi pengaruh yang berbeda pada berbagai variasi panjang stek. Dalam variabel jumlah akar lateral, volume akar, berat basah akar dan berat kering oven total. Perlakuan dosis 20 mg dengan panjang stek $45 \mathrm{~cm}$ merupakan kombinasi perlakuan terbaik.

Dari kesimpulan diatas dapat disarankan penelitian lanjutan perlu dilakukan dengan tidak menggunakan polybag tetapi langsung kelapangan untuk memperoleh hasil yang lebih nyata, terutama pengaruh panjang stek. Dengan kondisi lapang ruang tumbuh akar tidak dibatasi.

\section{DAFTAR PUSTAKA}

Anonim. 2008. Budidaya Buah Naga.http:/ /infokebun.wordpress.com.(26 Desem-ber 2011).

Anonim. 2010. Http://www.gerbang pertanian.com/ zat pengatur tumbuh tanaman html. Diakses tanggal 31 januari 2016 jam 17.15.35 
BPS Buleleng.go.id/fronted/linkTablet/Stat is/vlew/id/21 Diakses tanggal $1 \mathrm{Mei}$ 2016 jam 12.0512

Febriana, S. 2009. Pengaruh Konsentrasi ZPT dan Panjang Stek terhadap Pembentukan Akar dan Tunas pada Stek Apokad (Persea Americana Mill). Skripsi; Institut Pertanian Bogor. Bogor.

Kristanto, D. 2014. Berkebun Buah Naga. Penebar Swadaya. Jakarta.

Moko, H. 2004. Teknik Perbanyakan Tanaman Hutan Secara Vegetative. Informasi Teknis 2(1): hal. 1-20.

Nilayani, L.S. 2014. Pengaruh Dosis Rootone-F dan Jenis Media Terhadap Pertumbuhan Stek Anggur (Vitis Vinifera) Cultivar Belgia. Fakultas Pertanian Universitas Panji Sakti Singaraja.

Nuryana A. 2012. Kajian Komposisi Media dan Panjang Stek Terhadap Pertumbuhan Bibit Tanaman Buah Naga (Hylocereus Costaricensis).
Http.respository.unri.ac.id. Diakses tanggal 16 januari 2016 jam 12.5.10

Parnata, A.S. 2010. Meningkatkan Hasil Panen dengan Pupuk Organik. Pt Agromedia Pustaka. Jakarta.

Pranoto, C. 1986. Pengaruh Pemberiaan IBA dan Campuran IBA-NAA Terhadap Keberhasilan Stek Cemara Kipas (Thuja orientalis L.). Laporan Karya Ilmiah. Fakultas Pertanian. Institut Pertanian Bogor. Bogor.

Rahardja. P.C. dan Wahyu Wiryanta. 2003. Aneka Cara Memperbanyak Tanaman Agromedia Pustaka Tanggerang.

Triatmaningsih, R. 2009. Teknologi Budidaya dan Prospek Pengembangan Buah Naga (Hylocereus sp.). Balai Penelitian Tanaman Buah Tropika. Padang.

Wattimena, G.A. 1988. Zat Pengatur Tumbuh. Pusat Antar Universitas Institut Pertanian Bogor Bekerja Sama dengan Lembaga Sumberdaya Informasi -IPB 